\title{
Edebiyat Tarihi Yazımında Bir Kaynak Olarak Takrizler ve Sıra Dışı İki Örnek
}

\author{
NAGIHAN GÜR*
}

\begin{abstract}
ÖZ
Osmanlı edebiyatında önemli bir yere sahip olan takrizler, kendine has bir gelenek meydana getirmiştir. Bir eseri veya yazarı övmek için kaleme alınan bu metinler, genellikle eserlerin giriş kısımlarında yer alır. Bu gelenek, aynı zamanda, Osmanlı edebiyatı araştırmaları için birincil kaynak olma özelliği taşır. Öyle ki bazı takriz örnekleri, yazar ve esere dair içerdikleri bilgilerle biyografi ve monografilerin yazımına kaynaklık edecek niteliktedir. Bu çalışmada, edebiyat tarihi yazımında birincil kaynak olarak değerlendirilebilecek takrizlerin ne gibi işlevler taşıdıkları sorgulanacaktır. Keçecizâde İzzet Molla'nın Mihnet-kȩsân'ına ve Mahmûd Celâleddin Paşa (Âsaf) Divanina yazılan takriz örneklerinin inceleneceği bu çalışmada, edebiyat tarihini yeniden yazmak adına takrizlerin nasıl işlevler üstlendiği ve biyografi yazınının satır aralarını doldurmada bu metinlerin nasıl bir öneme sahip oldukları ortaya konulmaya çalış1lacaktır.
\end{abstract}

Anahtar sözcükler: Takriz geleneği, edebiyat tarihi yazımı, Osman11 edebiyatı, Mihnet-keşân, Keçecizâde İzzet Molla, Âsaf Divanı, Mahmûd Celâleddin Paşa

$\mathrm{B}$ ütünlüklü bir edebiyat tarihi yazımından söz etmek ne derece mümkündür? Bu soruya cevap arayan birçok araştırmacı bugün mevcut literatürün farklı açılardan nasıl değerlendirilebileceği ve bu literatürü destekleyecek/

* Yrd. Doç. Dr., Ankara Sosyal Bilimler Üniversitesi, Türk Dili ve Edebiyatı Bölümü/ANKARA E-posta: nagihan.gur@asbu.edu.tr Bu makale, tarafımızca hazırlanan "Klâsik Türk Edebiyatında Takriz Geleneği” (2014) başlıklı basılmamış doktora tezinden özgünleştirilerek üretilmiştir. 
zenginleştirecek yeni kaynakların nasıl işlevselleştirilebileceği sorunsalıyla karşı karşıya kalır. Osmanlı edebiyatı bağlamında düşünüldüğünde ise öncelikle mevcut kaynakların sınırlarının ve bu kaynakların ne derece "tamam/ lanabilir" olduğunun sorgulanması gerekir.

Bu noktada takriz yazını önemli bir yerde durmaktadır. Osmanlı edebiyat geleneğinin içerisinde kendisine hatırı sayılır bir yer bulmuş olan takrizler, edebiyat tarihinin satır aralarını doldurmada önemli bir rol üstlenir. Peki salt övücü nitelikte metinler olarak değerlendirilen ve hakkında sınırlı sayıda araştırma bulunan ${ }^{1}$ bu metinlerin bugün edebiyat tarihi yazımına kafa yoran araştırmacılara söyleyecek bir sözü var mıdır? Bu soruya birtakım örnekler üzerinden cevaplar bulmaya çalışmadan önce takrizin ne olduğuna kısaca değinmek uygun olacaktır.

Türk Dil Kurumunun Güncel Türkçe Sözlük'ünde “Övme, övüş, bir eserin başına konulan yetkili bir kimsenin yazdığı, övücü tanıtma yazısı, beğence” şeklinde yer alan takriz, en genel anlamıyla, "Bir müellifin eserine genellikle müellifin ricası üzerine dönemin önde gelen âlim ve ediplerinin yazdı̆̆ övücü takdim yazıları" (Uzun-Arslan 2010: 472) olarak tanımlanmıştır. "Bir telife medih yollu yazılan mensur veya manzum makale" (Lügat-i Naci 2009: 658) yâhut "bir telifi mensur veya manzum bir makale-i mahsûse ile medh ü sena etme" (Kamus-i Türki 1317: 426) şeklinde de tanımlanan takrizler, birçok sözlük ve ansiklopedi maddesinde "salt bir kelime olarak değil edebiyata ilişkin bir terim olarak" (Karataş 2000: 14) açıklanmıştır. Takrizlere dair yapılan bu tanımlar, şüphesiz, söz konusu metinlerin edebî gelenekteki kullanımlarıyla doğrudan ilişkilidir.

Takrizler hemen hemen her dönemde üretilmiş ve bir yazım türü niteliği kazanmıştır. Öyle ki 16. yüzyıldan 20. yüzyıla kadar süregelen edebiyat geleneğinde üretilen divan, mesnevi, mecmûa, tezkire, sözlük, sakînâme, sûrnâme, nasihatnâme, menâkıbnâme gibi türlerin yanı sıra belâgat kitapları, tarihler, müstakil manzumeler, şerh metinleri ve roman gibi birçok farklı eser ve türe takriz ${ }^{2}$ yazılmıştır. Bu yazının ilk örnekleri klasik edebiyat öncesinde de üretilmiştir. Kutadgu Bilig'e Çin âlimleri tarafından (Arat 2003: 5-7), Atabetül Hakayık'a Emir Seyfeddin ve Arslan Hoca Tarhan tarafindan yazilan takrizler (Arat 2006: 100) bu geleneğin Türk edebiyatında ne kadar geriye götü-

Takrizlere ilişkin yapılan çalışmalar şöyledir: Karataş, 2002; Vesely 2003; Rosenthal 1981; Woodhead 2000; Levanoni 2013; Gür 2012; Gür 2014; Bauer 2014; Burak 2015; Elçi 2016.

2 Takrizleri bir yazım türü olarak değerlendiren "Klasik Türk Edebiyatında Takriz Geleneği” başlıklı doktora tezinde 16. yüzyıldan 20. yüzyıla kadar 71 farklı metne/esere yazılmış ve "takriz" başlı̆ı̆nı taşıyan 200'e yakın manzum-mensur takriz örneği incelenmiştir. Detaylar için bakınız: Gür 2014: 6-39. 
rülebileceğini gösterir. Tanzimat ve modern edebiyat dönemlerinde de takriz örneklerine rastlamak mümkündür ${ }^{3}$.

Bugün, takrizleri salt övücü nitelikte metinler olarak değerlendiren ve bu metinlerin klişe yargılar içerdiğini ileri süren birtakım kanaatler mevcuttur. $\mathrm{Bu}$ kanaatler, eserden bağımsız olduğu düşünülen takrizlerin göz ardı edilmesine ve bazı metin neşirlerinde takrizlere yer verilmemesine yol açmışır. Bugüne kadar görmüş olduğumuz takriz örnekleri bizi bu kabullerin sihhatini sorgulamaya, takrizlerin eser ve yazarla kurduğu ilişkiyi irdelemeye ve bu yazının üretildikleri dönemde ve sonrasında ne gibi işlevler üstlendiklerini düşünmeye yöneltmiştir. Bu bağlamda İbnülemin Mahmûd Kemâl İnal'ın Leskofşalı Gâlib ${ }^{4}$ Divanina yazdığı ön söz bizim için önemli bir çıkış noktası olmuştur. İbnülemin, bu ön sözde Namık Kemâl'in Leskofçalı Gâlib'e yazdığı takrizden şöyle söz eder:

[Namık Kemâl'in] mutavvel ve mufassal takrîzi müessirle eser hakkında elbette şâyân-1 ehemmiyet ma'lûmât ve mülâhazât ihtivâ eylemiştir ki -divanı kadar hâiz-i kıymet olan- o takrîzin bugün elde bulunmaması, seza-vâr-1 esef-i azîmdir. Elde bulunsayd1, Gâlib Bey’i pek yakından tanıyan bir üstâd-1 sâhib-kemâlin tahkîkât ve mütâla'âtı şimdi bu sahifeleri tezyîn ve istifâde-i mükemmelemizi te'mîn ederdi (Y1ldiz 2003: 43).

Görüldüğü üzere Namık Kemâl'in söz konusu takrizi ${ }^{5}$ Leskofçalı Gâlib Bey'in Divan'ı kadar değerli görülmüştür. İbnülemin'in takrize yüklediği bu anlam, söz konusu metnin döneminde belirli bir sosyal ağın içerisinde do-

3 Turan Karataş'ın Takriz Edebiyatı (2002) adlı kitabı Tanzimat dönemi takriz örneklerini içermesi açısından önemli bir kaynaktır. Bunun yanı sıra klasik dönem takriz geleneğinin devamı olarak görebileceğimiz bazı takriz/takdim yazıları modern zamanda da varlık göstermiştir. Ahmet Talat Onay'ın Eski Türk Edebiyatında Mazmunlar ve İzahı (2000) adlı kitabına Tahir Olgun ve Velet Çelebi İzbudak'ın “Tebrik ve Teşekkür” amacıyla birer takriz yazmaları buna güzel bir örnek oluşturur. Bu takrizler eserin baş kısmında yer almaktadır. Benzer şekilde Ali Nihat Tarlan, Yahya Bey Divaninın (1983) edisyonunun tamamlanması üzerine Mehmet Çavuşoğlu'nun çalışmasına bir tarih yazmıştır. Bu tarih manzumesi, Yahya Bey Divani'nın edisyonunun baş kısmına konulmuştur. Bu bağlamda söz konusu tarih, modern anlamda bir tarih-takriz özelliği göstermektedir. Benzer şekilde, Ömür Ceylan'ın, Fatih Köksal'ın Tenkit ve Teori (2012) adlı kitabı ile Ahmet Kartal'ın Şiraz'dan İstanbul'a Şiir Rüzgarları: Türk-Fars Kültür Coğrafyası Üzerine Araștırmalar adlı eserine yazdığı takrizler ve Mehmet Fatih Köksal'ın Ziya Avşar'ın Aşk Meclisi: Mesneviye Yeniden Uyanmak adlı kitabına yazdığ ${ }_{1}$ Farsça takriz de yine bu bağlamda anılmaya değerdir.

4 Encümen-i Şu'arâ topluluğu şairlerinden olan Leskofçalı Gâlib Bey (öl. 1867) kaymakamlık, Bahriye kitâbeti ve divan kâtibliği gibi görevlerde bulundu. Ercümen-i Şu'arâ topluluğu daha ziyade Gâlib’in şiir çevresinde teşekkül etmiştir. Şiirin muhtevasında eski şairler gibi davranan Gâlib, bunu ifade ediş ve sunuş bakımından yenidir. Şairin bugün bilinen dört adet mektubu ile bir divanı vardır (Yı1dız 2003: 140).

5 Söz konusu takriz Midhat Cemal Kuntay'ın Namık Kemal: Devrinin İnsanları ve Olayları Arasında adlı eserinde tıpkıbasım şeklinde bulunmaktadır (bkz. 1949: 31). 
laşımda olduğuna da işaret emektedir. Bu ifadeler aynı zamanda takrizlerin eserlerden bağımsız olarak bir değerinin olabileceğini ve bu metinlerin üretildikleri dönemlerde dahi bir başvuru kaynağı olarak görüldüklerini ortaya koymaktadır.

Edib Ahmed Yükneki'nin Atabetül-Hakâyık'inda -eserin her nüshasında bulunmayan ve farklı başlıklarla karşımıza çıkan- biri isimsiz diğerleri ise döneminin önemli devlet adamı-hâmileri tarafindan yazılmış üç takriz ${ }^{6}$ yer alır. Reşit Rahmeti Arat tarafindan bilimsel yayımı yapılan eserin inceleme ve notlar kısmında doğrudan "takriz" (Arat 2006: 127) olarak adlandırılan bu manzumeler, yazar ve eser hakkında dikkate değer hükümler içerir. Edib Ahmed'in fiziksel özellikleri, nereli olduğu, babasının adının ne olduğuna dair birtakım detay bilgiler içeren bu takrizler eserin dili, içeriği, edebi değeri ve döneminde gördüğü ilgiyi ortaya koyması açısından önemlidir. Reşit Rahmeti Arat, bu manzumelerden hareketle şöyle bir tespitte bulunur:

"Eserin bu ilaveler [takrizler] ile birlikte yeniden tanzim edildiği tarihlerde, Edib Ahmed'in hâl tercümesi o muhitte artık meçhûl olup, adı, yeri ve hattâ eserinin ismi bile tereddütlü ve şüpheli bulunuyordu. Bilhassa Arslan Hoca Tarhan'ın [takrizindeki] sözleri bu ciheti açıkça göstermektedir" (Arat 2006: 7).

Arat'ın bu tespitleri Atabetül-Hakâyk'a yazılan takrizlerin Edib Ahmed'in biyografisini ve eserini bugüne taşımada önemli bir rol üstlendiğini açıça gösterir.

Bu bağlamda Mehmet Fuat Köprülü'nün Yenipazarlı Vâlị̂ (öl. 1589)'nin Hüsn ü Dil adlı mesnevisine Bâkî (öl.1600) ${ }^{8}$ tarafindan yazılan takrizden hareketle yaptığ 1 değerlendirmeleri de dikkate değerdir:

991 (1584)'de şair Vâlî, Âhî̉nin meşhur Hüsn ü Dilini nazmederek devrin belli başlı şairlerinden takrizler aldığı sırada, Bâkî̀den de takrîz almış ve bunun üstüne ilave ettiği ser-nâmede ${ }^{9}$, Bâkî hakkında "mâlik al-şu'arâ" unvanını kullanmıştı. Bu unvan sonradan umûmiyetle kabul

6 Bu manzumeler için bkz. Arat 2006: 100.

7 Vâli Ahmed Çelebi, Hoca Sâdeddin Efendi'ye mülâzım olmuş kadıllk görevinde bulunmuştur. Hüsn ü Dil adlı mesnevisiyle şöhret bulmuştur (Sicill-i Osmânî, 5. Cilt, 1650).

8 Şöhret ve tesiri asırlarca devam eden, klasik Osmanlı şiirine söyleyiş gücü kazandıran ve "Sultânü'şşuarâ" diye anılmış büyük divan şairi Mahmud Abdülbâki (Bâkî) (öl. 1600), Süleymaniye Külliyesi’nde bina emini, kadılık, kadı nâibliği, Sahn müderrisliği, Anadolu ve Rumeli kazaskerliği görevlerinde bulundu. Şiirlerinde temiz ve âhenkli bir üslûba sahip olan Bâkî, Osmanl şiirine bir söyleyiş kudreti ve rahatlı̆̆ı kazandırmıştır. Divan, Fezâilü'l-cibâd ve Fezâil-i Mekke, Meâlimül'-Yakîn, Kırk Hadis Tercümesi adlı eserleri vardır (Çavuşoğlu 1991: 537-540).

9 Söz konusu takrizin başlığı şöyledir: “Melikü’̧-Şu’arâ Kıdvetü’l Fuzelâ Bâkî Efendi”. 
edilmiş ve Bâkî hakkında dâimâ "mâlik al-şu'arâ" ve daha ziyade "sultan al-şu'arâ” unvanı kullanılmıştır (Köprülü 1979: 249).

Her ne kadar Köprülü’nün Bâkî̀nin unvanına ilişkin bu tespitini başka kaynaklarla destekleyemiyor olsak $\mathrm{da}^{10}$ bu ifadeler takrizlerin işlevi ve edebiyat tarihi açısından taşıdıkları değeri göstermesi açısından önemlidir. Bu örnek aynı zamanda takrizlerin onu üreten kişiler açısından da bir değer taşıyabileceğine işaret eder. Diğer yandan bu takriz, salt takriz başlıklarının dahi bugünün araştırmacılarına söyleyecek birçok şeyi olabileceğini göstermektedir. Bu noktada, bu geleneğe yüklenen değeri somutlaştırmak ve takrizlerin edebiyat tarihi yazımında ne gibi işlevler üstlenebileceğini sorgulamak adına birtakım takriz örneklerini irdelemek uygun olacaktır.

Keçecizâde İzzet Molla (öl. 1829)'nın ${ }^{11}$ “yerleşik geleneğin dışına çıkan özellikleri dolayısıyla hem çağında hem de sonraki dönemlerde "temkinli” bir ilgiyle karş1lan[an] (Tüzin 2008: 8) Mibnet-keşân adlı mesnevisine Sahaflar Şeyhizâde Es'ad Efendi ${ }^{12}$ (öl. 1848) uzun soluklu bir takriz yazar. Eserin nazım şekliyle uyumlu olan bu manzum takriz Es'ad Efendi Divaninda “Takrîzât” başlığı altında yer alır. Söz konusu takriz adeta Sahaflar Şeyhizâde Es'ad Efendi ve İzzet Molla'nın müşterek bir sergüzeştnâmesi niteliğindedir. Kendisi aynı zamanda İzzet Molla'nın bacanağı olan ve bu bağın tesiriyle samimi bir üslupla takrizini kaleme alan Es'ad Efendi, söz konusu takrizinde İzzet Molla’nın sanatını şu şekilde değerlendirir:

$$
\begin{aligned}
& \text { [...] } \\
& \text { Ma'ānīsi rengīn ḥurūfu ḥarīf } \\
& \text { O maẓūfun el-ḥak zurūūı ẓarīf } \\
& \text { Olup lafẓ u ma'nāsı şekkerle şīr } \\
& \text { Aya nān u helvā degildir naẓīr }
\end{aligned}
$$

$10 \mathrm{Bu}$ tespite Haluk İpekten, Bâkî üzerine hazırladığı, Bâkî: Hayatı, Edebi Kişiliği ve Bazı Şiirlerinin Açıklamaları adlı kitabında -Mehmet Fuat Köprülü’yü referans alarak- yer vermiştir (İpekten 2008: 25-26).

11 Osmanlı şiirinin 19. yüzyıldaki son temsilcilerinden olan Keçecizâde İzzet Molla (öl. 1829) müfettişlik, kethüdâlık ve kadılık görevlerinde bulundu. Gerek divanındaki manzumelerde gerekse mesnevilerinde mahallî renkler ve yerli unsurlar dikkati çekecek derecede çoktur. İzzet Molla'nın asıl başarısı

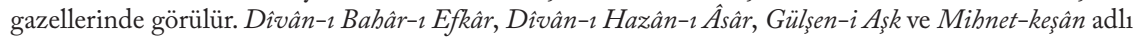
eserleri vardır (Okçu 2001: 561-563).

12 Babasının sahaflar şeyhi olması itibariyle Sahaflar Şeyhizâde olarak anılan Es'ad Efendi (öl. 1848) vakanüvislik, takvimhâne nâzırlığı ve kadılık gibi önemli görevlerde bulunmuştur. Yeniçeri Ocağı'nın kaldırılmasını anlatan $\ddot{U}_{s s-i}$ Zafer adlı şöhret bulmuş eserinin takdimiyle kendisine Evkaf müfettişliği ve Üsküdar mahreci pâyesi verildi. Es'ad Efendi ayrıca nadide eserlerden derleyip vakfettiği kitaplarla da ilim çevrelerinde müstesna bir yere sahip olmuştur. Eserleri arasında Divan'ı ve Üss-i Zafer anılmaya değerdir (Yılmazer 1995: 341). 
Mis̄āl-i Nedīm-i ma‘ārif-nişān

Eder bezme enseb ma'āni beyān

Makāmāt'1 görmüş degilsen eger

Bunu ezber eyle edebden yeter

Mizāc-1 mizāḥ-āşināsı eger

Dilerse sözünden ḥacerler güler

Bulur bāde-nūşāne meşrebce söz

Koyar lūle-i ehl-i keyf üzre köz

Olup vā'iẓe geh medār-1 kelām

O dürden verir silk-i nuṣha nizām

Beyān-1 kerāmātı etse murād

Mürīdi olur merd-i rūşen-nihād

(Süleymaniye Kütüphanesi Esad Efendi 1749: 8b)

Bu övücü söyleminin ardından söz konusu takrizin 22. beytinden itibaren Sahaflar Şeyhizâde Es'ad Efendi kendi hayatına dair birtakım bilgilere yer verir:

Çıḳıp emr-i tahrīre ḳırk altıda

Gezildi rehin üstü de altı da

O yolda perişsān iken dürr-i dem‘

Refikịim olup ḩāṭ̂rım itdi cem‘

Kalem oldu şīrāze-bend-i șenā

Bu nazm ile verdikde Sofya safā

(Süleymaniye Kütüphanesi Esad Efendi 1749: 9a)

Es’ad Efendi'nin “1831'de yapılan nüfus sayımında Şehirköy ve Sofya yöresinde görevlendir[ilişine]" (Arslan 2005: XIV) gönderme yapan bu ifadeler söz konusu takrizi adeta Sahaflar Şeyhizade Esâd Efendi' nin bir sergüzeştnâmesi olarak okumamıza imkân sağlar. Bu niteliğiyle bir tür takriz-sergüzeştnâme özelliği gösteren bu melez takriz, aynı zamanda bu geleneğin sıra dışı bir örneği olarak karşımıza çıkmaktadır.

Takrizinin 33. beyitinde tekrar İzzet Molla'ya dikkat yönelten Sahaflar Şeyhizâde Es'ad Efendi, İzzet Molla ve Hâlet Efendi arasındaki ilişkiye de göndermede bulunur. Şairin gerek siyasi gerekse edebî birçok faaliyetinde önemli bir kimlik olan Hâlet Efendi, İzzet Molla'nın hem iyi hem de kötü tâlihi olmuştur. Devlet kethüdalarından Hâlet Efendi ile tanışan İzzet Molla 
kısa sürede "Hâlet Efendi'nin nedimleri arasına girmiş ve o vasıta ile Sultan Mahmûd'un mülakat ve iltifatına nâil ol[muştur]" (İstanbul Kütüphaneleri..., 1965: 980-981). Sahaflar Şeyhizâde Es’ad Efendi de İzzet Molla gibi Hâlet Efendi'ye intisap etmiş ve onun meclislerinde bulunmuştur (Oğraş 2001: 4). Böylelikle İzzet Molla ve Hâlet Efendi arasındaki ilişkiye tanıklık etme firsatı da bulan Es'ad Efendi, bu yakınlığı yazmış olduğu takrizine de yansıtmayı ihmal etmez. "Hâlet" kelimesinin tevriyeli kullanımıyla taraflar arasındaki ilişkiye gönderme yapan Es’ad Efendi şairin sürgün nedenini şu şekilde dile getirir:

O eșnāda ber-ḳavl-i mihnet-keşān

Düşer hālet-i hicrete nāgehān

(Süleymaniye Kütüphanesi Esad Efendi 1749: 9a)

Hâlet Efendi'nin Konya'ya sürülüp orada idam edilmesinin ardından İzzet Molla bir anlamda ondan gördüğü lütuf ve keremin şükrünü îfâ etmiş olmak için Hâlet Efendi'nin müdafaasında bulunmuş ve bu nedenle Keşan'a sürülmüştür (İstanbul Kütüphaneleri..., 1965: 980-981). Es'ad Efendi’nin bu takrizinde şairin hayatında bir dönüm noktası olan ve mesnevisini kaleme almasını sağlayan söz konusu hadiseye gönderme yapılması bu takrizin belirli bir bağlamda üretildiğini açıkça göstermektedir. Bu örnek, aynı zamanda takriz metinlerini çözümlemede tarihsel, sosyal ve kültürel zeminde yapılacak farklı okumaların önemine de işaret etmektedir.

Sahaflar Şeyhizâde Es'ad Efendi'nin takrizinde şairin ikinci sürgün yeri olan Sivas'a da yer verilir. Bu kısımlar, İzzet Molla'nın sürgününe sebep olan ve onun lâyihâsını II. Mahmûd'a bildiren (Ceylan-Yılmaz 2005: 23) Behçet Bey'e dair şu göndermeleri içerir:

Leb-i Behçet'i bu sebebden meded

Kapandı be-tezvīr-i ehl-i hased

Erācīfe bā'is olur șoḥbeti

Denip dūra țard etdiler 'İzzeti

Sakın nā-becā açma ḳaṭ‘ā dehen

Olursay da șādı̣ çekersin ziyān

Der-enbār olan gendüm-i sebze-dār

Bu ma'nāyı eyler saya āşikār

Ḥudā șaḳlasın cümleyi ez-ḳażā

$\mathrm{Bu}$ hefve eder nefyini iḳtizā 
Ṭariḳin edip țayy ḳażā-yı Hudā

Sürer sūy-1 Sīvās'a esb-i celā

Ṭoḳuz māha vardıḳda hengām-ı hicr

Baḳın ne togurdu 'acūz-1 sipihr

(Süleymaniye Kütüphanesi Esad Efendi 1749: 9b)

Yukarıda yer alan "Tokuz mâha vardıkda hengâm-1 hicr/Bakın ne toğurd1 'acûz-1 sipihr" şeklindeki beyit -kaynaklarda yer aldığ1 şekliyle ${ }^{13}$ - İzzet Molla'nın ikinci sürgün yerinde dokuz ay kaldığını teyit etmektedir. İzzet Molla'nın ihtiyatsızlı̆̆ına, çevresindekilerin onun sürgününde oynadıkları role ve şairin hayatındaki önemli dönüm noktalarına göndermeler içeren bu beyitler söz konusu takrize âdeta tarihî bir belge/şiir niteliği kazandırmıştır.

Sahaflar Şeyhizâde Es'ad Efendi'nin söz konusu takrizinde şairin edebî üretimleri de mercek altına alınmıştır:

Nu'ūtı olur Bür'e derd-i dile

Şefā'atle men'ūtı virsün șıla

Kașā’id ki Nef'ì olaydı eger

Mu'āṣır çeker şöhretinden żarar

Ġazāl-i Cemāli ġazel șayd eder

Gümüşs sāḳını maḳța'ı ḳayd eder

Rubā‘īisini rub'-1 meskūnda nās

Sezā etseler ḳaṣr-1 naẓma esās

Bulur müfredinden revā serv-i yār

Miyān-1 muhibbānda nev-iştihār

Meșāri‘ ki āzāde ig̉lākdan

Açar beyt-i rengīne bāb-1 dehen

Tevārīh-i şināsı öyle metīn

Surūrī’yi g̀ıbțayla itdi ḥazin

(Süleymaniye Kütüphanesi Esad Efendi 1749: 10a)

Şairin sanatına ne derece vakıf olduğunu gösteren bu kısımların ardından Sahaflar Şeyhizâde Es'ad Efendi, İzzet Molla'nın edebî faaliyetlerinin bir dökümü de sunmuştur:

13 Keçecizade İzzet Molla 1841; Ceylan-Yılmaz 2005; Arslan 2010. 
Ķodu Gülşen-i ‘Aşḳ adın birine

Hezārın getirdi huşun yerine

Șabāvet sözüyken n'ola ol sühan

Olur gāalib-i güfte-i şeyh-i fen

Diger meșnevī ismi Nāz u Niyāz

Ușūlü ser-ā-pāy sūz u güdāz

Tamām olmadan līk ecel șad dirīìg

Meh-i ‘ömrünü örtdü mānend-i mīì

Siyāh-1 ḥurūfa işāret edip

Yine cem‘-i dīvāna niyyet edip

Anı̀ nāmın etdi Ḩazān-ı Bahār

Birazcık da olmuş iken sebze-vār

(Süleymaniye Kütüphanesi Esad Efendi 1749: 10a)

Görüldüğü üzere bir biyografi maddesinde yer alabilecek bütün bilgileri hatta -daha fazlasını- içeren Sahaflar Şeyhizâde Es'ad Efendi'nin bu takrizi ${ }^{14}$, İzzet Molla'nın biyografisini takip etmede bugünün araştırmacılarına önemli bilgiler sunmaktadır. Bu takriz ayrıca şairin bazı tezkire maddelerinde ve güncel çalışmalarda yer almayan ${ }^{15}$ Nâz $u$ Niyâz adlı tamamlanmamış mesnevisinden bizi haberdar eden ilk kaynak olması bakımından da önemlidir. "Şeyh Gâlib’in Hüsn ü Aşk mesnevîsine nazîre olarak tasarlandığı" (Şahin 2013: 158) düşünülen bu mesnevi, İzzet Molla'nın yarım kalmış "son teşebbüsü”dür (Şahin 2013: 151). Takrizde yer alan bu bilgilerden hareketle söz konusu mesnevinin peşine düşen Ebubekir Sıddık Şahin eserin iki farklı nüshasın1 ${ }^{16}$ tespit etmiş ve bunun üzerine "Hüsn ü Aşk'ın İzinde Yarım Kalan Bir Mesnevî: Nâz u Niyâz” başlıklı bir makale yazmıştır. Söz konusu eseri

14 Sahaflar Şeyhizâde Es‘ad Efendi'nin yukarıda aktardığımız bu uzun soluklu takrizi karşılıksız kalmamış, Es'ad Efendi'nin Üss-i Zafer adlı eserine Keçecizâde İzzet Molla da bir takriz yazmıştır. Es‘ad Efendi'nin vekâyinüvis olduğu sırada yazdığı [Üss-i Zafer], olayların içinde bulunmuş bir kişinin kaleminden çıkmış olması, askeri alanda yapılan yenilikler ve yeniçeriliğin kaldırılmasını ayrıntılı olarak anlatan başka bir eserin bulunmaması açısından (Arslan 2005: XXXII) önemli bir kaynaktır. Takrizinde eserin bu yönüne dikkat çeken İzzet Molla, Es'ad Efendi'nin vakanüvisliğine dair değerlendirmelerde bulunmuştur. Takrizde ayrıca eserin basımına dair birtakım bilgilere de yer verildiği görülür.

15 İzzet Molla'nın Nâz u Niyâz adlı mesnevisi, şair üzerine yapılmış bazı çalışmalarda eserleri arasında yer almamaktadır. Bkz: İnal 1988: 722-746; Okçu 2001: 562-563; Ömür Ceylan-Ozan Yılmaz 2007: XXXVI. Bu kaynakların yanı sıra şairin söz konusu mesnevisine dikkat çeken bazı çalışmalar da mevcuttur. Bkz: Özyıldırım 2007: 27; Şahin 2013: 151.

16 Eserin nüsha kayıtları şöyledir: "Süleymaniye Kütüphanesi Esad Ef. 2934, yk. 37b-45b; Dârü'1Kütübi'l-Misriyye, Edebü’t-Türkiyye 1839, yk. 42b-53a”(Şahin 2013: 151). 
dikkatimize sunan bu yayım, takrizlerin edebiyat tarihi araştırmalarına sağladığı katkıyı somutlaştırması açısından dikkate değerdir.

Takrizlerin içeriklerinin değerlendirilmesinde önemli bir diğer örnek $\hat{A}$ saf Divaninda karşımıza çıkar. "Sultan Abdülmecid'in kızıyla evlenen ve aynı zamanda saray görevleri sırasında kayınbiraderi Sultan Abdülhâmid'in yakınlığını kazanan (Ceylan 2003: III) Dâmâd Mahmûd Celâleddin Paşa (öl. 1903)'nın ${ }^{17}$ saraydaki iyi konumu çok uzun sürmemiş ve nihayetinde padişahın iltifatından uzak kalmıştır. Siyasi kimliğinin yanı sıra Âsaf mahlasıyla şiirler yazan Paşa'nın evi şair meclislerinin de en popüler mekânı olmuştur (Ceylan 2003: 21) $)^{18}$.

Asaf Divaninda iki manzum takriz yer alır. Şairin sanatının övüldüğü bu takrizlerden ilkinin içeriğ i̧i şöledir:

Pür-ma ‘ālidir kasāid meclis-ārā söz değil

Medh-i şāhı benzemez Şehnāme'nin destānına

Pür-ḥakikat cümlesi ez cümle ol "İntāk-1 Hak"

Hak Te‘ālā'nın güzel tefsìrdir Kur'ān'ına

"Hizb-i Bahr"in zevki țab"-1 müstaḳimi coşdurur

Çāredir ammā saḳāmet zeenbinin țūfānına

(Süleymaniye Kütüphanesi İhsan Mahvi 94: 2-3)

Divanda yer alan diğer takriz de benzer şekilde şairin sanatını övücü bir söylem içerir:

O "Ḥizb"-i güzīden o "İntāk-1 Ḥaḳk"

Sir-1 nāme-i fikret-i mā-sebak

'Arabdan 'Acemden gelen şā‘irān

İşitmiş mi hiç böyle bir dāsitān

Kelāmın ḩoş-üslūb u dil-cūydur

Çemen-zār-1 țab'in da ḩoş-būydur

17 Sultan Abdülmecid'in kerimelerinden Seniha Sultan ile evlenen Mahmûd Celâleddin Paşa (18531903), Sadaret Mektubî Kalemi memurluğu, nazırlık ve vezirlik görevlerinde bulundu. Şiirlerinde "Âsâf” mahlasını kullanmıştır. Şairliğinin yanı sıra aynı zamanda iyi bir hami olan Âsâf'ın evi, meyhaneler ve kahvelerden sonra toplanılan büyük konaklardan biri olmuştur (İnal 1988: 41-50).

18 İbnülemin Kemal İnal, Celâleddin Paşa'nın etrafında oluşan, aralarında Üsküdarlı Sâfînnin de bulunduğu sosyal ağa şu şekilde işaret eder: "Meclisi encümen-i şiir idi. Erbâb-1 şiir, o encümene devam eder ve encümende isbat-1 vücut ederdi. [....] Şair Üsküdarlı Talât ve Sâfî Beyler, encümenin âzây1 dâimesindendirler. Erbâb-1 kemâlden diğer zevat da müdavim idiler. Fudaladan Abdurrrahman Süreyyâ Efendi ile Hüseyin Daniş Bey, Beylerin muallimlerindendiler” (İnal 1988: 1930: 60). 
Sitāyiş-gerindir zebān-1 'umūm

Senịle mübāhāt eder mülk-i Rūm

(Süleymaniye Kütüphanesi İhsan Mahvi 94: 8)

Âsaf' 1 sanat yetisini ortaya koyan bu takrizlerde şairin devrinde önemli etki yaratan "İntak-1 Hak" ve "Hizbü'l-Bahr" adlı kasidelerine gönderme yapıldığı görülür. İntak-1 Hak, Paşa'nın en bilinen manzumesidir. Ziya Paşa’nın Zafername'si tarzında yazılan bu kaside devrin bazı şairleri tarafindan tahmis edilmiştir. Ayrıca söz konusu kasidede, döneminde birçok eleştiriye hedef olan Bahriye Nazırı Hasan Hüsni Paşaya dair ağır eleştiriler de yer alır (Ceylan 2003: 35). Hizbü'l-Bahr'da ise 1897-1898 Türk-Yunan savaşlarında kazanılan zaferin anlatıldığı beyitler dikkat çekicidir. Ayrıca kasidede, Bahriye Nazırı Hasan Paşa'nın Sultan'a şikâyet edilmesini içeren bir bölüm de yer alır. Devrin sosyal durumunun bir panoromasını da sunan Âsaf, bu kasidede İntak-1 Hak’a göre daha sert bir üslup kullanmıştır (Ceylan 2003: 36).

Takriz yazarları Âsaf'ın bu sansasyonel kasidelerini övmüş ve bu şekilde Dâmâd Mahmûd Celâleddin Paşaya destek vererek dönemin nabzını tutmuşlardır. Bu takrizlerde dikkati çeken bir diğer önemli husus, takrizlerde şair mahlaslarının gizlenmiş olmasıdır. Bu durumu, yaşadığı siyasi baskının en yoğun olduğu dönemde Mısır'a giden, divanını orada bastıran ve eserin basım süreciyle bizzat alakadar olan Mahmûd Celâleddin Paşa'nın bir tasarrufu olarak değerlendirmek mümkündür. Divan'ın basımından önce yazıld1ğını düşündüğümüz ve -muhtemelen- Âsaf tarafindan, "Bir Şầir-i Meşhûrun Takrizi” ve "Bir Şầir-i Nükte-perverindir” şeklinde sonradan adlandırılan bu manzum takrizlerin "mahlassız" beyitleri şu şekildedir:

Şānını tavsîfden ‘ācizsin ey [...] fakat

'Aczini 'afv etmemek düşmez o zâtı̣ şānına

(Süleymaniye Kütüphanesi İhsan Mahvi 94: 5)

$\mathrm{Bu}[\ldots]$ saya bir kemīn-bendedir

'İnāyetine ḳarşı şermendedir

(Süleymaniye Kütüphanesi İhsan Mahvi 94: 8)

İncelediğimiz takrizler içerisinde ilk kez karşımıza çıkan bu sıra dışı örnek, söz konusu takrizlerin Paşa'yı destekleyen ve onun sosyal ağında bulunan birileri tarafından yazıldığını düşündürmektedir. Peki takrizlerde bilinçli bir şekilde kimlikleri gizlenen söz konusu kişiler kimlerdir? Bu sorunun kısmî cevabını İbnülemin Mahmûd Kemâl İnal'in şu ifadelerinden öğrenmekteyiz: "[Dâmâd Mahmûd Cemaleddin Paşa] İstanbul'da bulunduğu esnada Divan-1 Eş'arını Mısır'a gönderip tab ettirmek istedi ise de muvaffak olamadı. Bilahere Mısır'a azimetinde tab ettirmiştir. Üsküdarlı Sâfînnin pek latîf bir takriz-i manzûmunu hâvidir” (İnal 1988: 60). Görüldüğü üzere İbnülemin’in aktar- 
dığı bu bilgi, takriz yazarlarından birinin -Paşa'nın oğlu Prens Sabahattin’e hocalık yapmış olan- Üsküdarlı Sâfî olduğunu öğrenmemizi sağlar. Ancak hangi takrizin Sâfî̀ye ait olduğunu tespit etmemiz mümkün değildir. Öyle ki mahlas beyitlerinde yer alan boşluklara vezinden yola çıkarak "Sâfî" ismini yerleştirdiğimizde vezin gereği her iki dizede de iki heceye ihtiyaç duyulduğu görülür. Metin tamirine imkân vermeyen bu beyitlerde takriz yazarlarının kimliklerini bilinçli bir şekilde gizlediğini düşündüğümüz Mahmûd Celâleddin Paşa o dönemde İstanbul hükûmetinin baskısını üzerinde yoğun bir şekilde hissetmiştir. Bu noktada, Mısır'da bulunduğu sırada ciddi bir takip altında olan Paşa'nın böyle bir dönemde divanına takriz yazarak kendine destek veren kişilerin kimliklerini if̧̧a etmekten sakınması oldukça olağan bir durumdur. Mahmûd Celâleddin Paşa'nın bu korumacı yaklaşımını, aynı zamanda takriz yazarlarıyla arasında var olan sosyal ağın bir sağlaması olarak da okumamız mümkündür.

\section{Sonuç}

Yazıldıkları eser ve yazardan bağımsız olmayan takriz metinlerinin bugün edebiyat tarihinin satır aralarını doldurmada önemli bir rol üstlendiği görülmektedir. Öyle ki bu metinler -içerdikleri bilgi ve değerlendirmelerle- "mevcut malzemeden kotarılan bir üst metin” (Özgül 2013: 2691) olarak kurgulanan edebiyat tarihi yazımında bugün bizlere hatırı sayılır bir malzeme sunmaktadır. Bu bağlamda, Osmanlı dönemi takriz geleneğinin içinin doldurulması adına, edebiyat tarihi araştırmalarında birincil kaynak olarak kullanabileceğimiz bu metinlerin farklı açılardan yeniden değerlendirilmesi, mevcut tüm örneklerin detaylı bir şekilde analizlerinin yapılması ve bu metinlerin üretildikleri bağlamın irdelenmesi gerektiğini düşünmekteyiz. Bunun sağlanması adına, çeşitli takriz örneklerinden oluşacak bir takriz veritabanının hazırlanması ve mümkün olduğu kadar çok sayıda takriz örneğinin incelenmesi önemli bir adım olacaktır. Bu vesileyle, takriz metinlerinin detaylı bir dökümünü sunmak ve bu metinlere tarihsel, kültürel ve sosyolojik bağlamda yakın okumalar yapmak, şüphesiz, edebiyat ve kültür tarihi araştırmalarına önemli katkılar sağlayacaktır.

\section{Mihnet-keşân'a ve Âsaf Divani'na Yazılan Takrizler}

Mihnet-keşān, Keçecizāde 'İzzet Molla

Mevālī-i Fị̣āmdan Keçeci-zāde Meḥmed 'İzzet Efendi Merhūmun Miḩnetkeşān Nām Manẓūmesine Taḳrīìi ve Tercüme-i Ahvālini Hāīī Meśnevīdir 
Bā-cenāḥımız cennet-mekān Keçeci-zāde 'İzzet Mollā merḥūmuy tārīh-i hitāmı hatṭ̂-1 destiyle olup Celāl Efendi hafíidleri Ḥüsām Mollā ve Vāhid Mollā'ya müsveddesinden tertīb ve taḥīir etdirdigi Miḥnet-keşān nām manzūume-i belìgası berāy-1 tahrīr-i nüfūs Sofya'ya me'mūriyetimde ictirā' olduğu ḥālde der-dest-i istișhāâ-1 faḳīr olmagìla medīne-i mezbūrede teclīd ettirip āsitāneye iyābda gerdūne-nişīn iken ẓahrına terceme-i nāẓımı şehnāme [?] vezni üzre yazdığımız takrīzdir. Şa'bān 1246/1831

Feūlün Feūlün Feūlün Feūl

Hudā 'İzzet'in rūhunu şād ede

Kusūr-1 fürū'unda ābād ede

Ne hoş dendi bu beyt-i Türkīedā

Cevāhirle yazsa yerā'am revā

Cihānda kişinin adıdır kalan

Kalanı yalandır yalandır inan

Be-tevfiḳ-i Ḥaḳ nükteyi derk edip

Ḥayāt-1 ebed buldu gerçi gidip

Koyup çend eșer etdi ibḳā-yı nām

N'ola ḥaşre dek yād ederse enām

Degil mi eșer işbu 'ālī-güher

Süreyyā gibi çarha çıḳsa deger

Edinse sezā anı miḥnet-keşān

Ġamından rehā bulmag̉a ḥırz-1 cān

Ma'ānīsi rengīn ḥurūfu ḥarīf

O maẓrūfun el-ḥak zurūfi zarîif

Olup lafẓ u ma'nāss şekkerle şīr

Ana nān u hẹelvā degildir naẓīr

Mis̄āl-i Nedīm-i ma ārif-nişān

Eder bezme enseb ma āñi beyān

Makāmāt'1 görmüş degilsen eger

Bunu ezber eyle edebden yeter

Mizāc-1 mizāh-āşināsı eger

Dilerse sözünden ḥacerler güler 
Bulur bāde-nūşāne meşrebce söz Koyar lūle-i ehl-i keyf üzre köz

Olup vā'iẓe geh medār-1 kelām O dürden verir silk-i nușha nizām

Beyān-1 kerāmātı etse murād

Mürīdi olur merd-i rūşen-nihād

Mey-i hubb-1 bī-gıll-i șūfiyyeden Açar țab'-1 ser-şārı gāhī sühan

Olur gūş eden neşve-yāb-1 șafā

Gelir șadr-1 meşrūḥa andan şifā

Hele 'āşsk-1 dūr-1 dīdār-1 yār

Sezā cilve-gāh etse leyl ü nehār

Elifler ki üstündeki medd ile İrā'e eder hạācibi ḳadd ile

Degil mi baḳın devre-i ḥarf-i cīm Şebīh-i 'ižār-1 şemāme-şemīm

Siyah-1 hațı perçemi aydırır O gül-reng cezmi femi aydırır

Çıḳıp emr-i tahrīre ḳırḳ altıda Gezildi rehin üstü de altı da

O yolda perișān iken dürr-i dem Refiḳim olup ḩāṭ̂rım itdi cem‘

Kalem oldu şīrāze-bend-i șenā Bu nazm ile verdikde Sofya safā

Bu bir nüsḩadır kim ederse harāi Sühan-senc-i 'irfān serī zīveri

Bu bāg̣ın fusūli hemişse bahār Dimāg̣ın yerindeyse ḳ1l i'tibār

Budur nüsḥa-i evvelīn-i nefìs Yed-i nāẓım olmuşdur imzā-nüvis 
Ne nāẓm-1 Niẓāmīi-i sihr-āferīn

Eger görse Genc'in ider der-zemin

İki yüzde zātı olup nāşi’e

Nola olsa fenninde sāhib mi’e

Kodu șālih-i șadr-1 Rūm ol kerīm

Cihānda anı̀ gibi dürr-i yetīm

Alıp on ikide reviş-i tarīk

Reh-i naẓma hucūyi [?] itdi refīk

Otuz yedi içre o mihnet-zede

Kalātā’yı ḳıldı hukūmet-kede

O eșnāda ber-ḳavl-i mihnet-keşān

Düşer hālet-i hicrete nāgehān

Cihāndārı bin yıl yaşatsun Ḩudā

Senesinde ițlāḳ itdi sezā

Kadir-dānīi-i şāh-1 'ālem yine

Çevirdi șuyu eski mecrāsına

Keşān'dan gelip iki yıl geçmeden

Olur mazhar-1 iltifāt-1 kühen

Olup müstehak nuḳresi sikkeye

Çıkar süllem-i pāye-i Mekke'ye

Sitanbūl'u ḳırḳ üçde pāye ile

Kerem ḳıldı şevketli ol ḳābile

Żamīme edip emr-i teftīşi hem

Ma'aşında kem oldu teşvişsi hem

Edip nāẓır-ı defter evvel anı

Nüfūžunda ḳıldı mükemmel anı

İșābet edip līk 'ayn-1 kemāl

O ‘ayn-1 kemāle yetişdi zevāl

Erişdirdi keydin bu çarh̆-1 'anūd

Şerer șaçdı tennūr-1 ḥıḳd-1 hạāùd 
Olup ġurre-i rīş-ḩand-1 zamān

O meftūn-1 yārān-1 mārān-nişān

Hुilāl-i seferde düzer hod-be-ḩod

Bir efsāne-i şūr u gavàgā-nümūd

Eder silmi tercịh-i ceng üstüne

Velī gitmedi pek direng üstüne

Eder yār u ag̉yāre bu sırrı fāş

N'ola 'akl-1 fa'āle gelse telāş

Leb-i behçeti bu sebebden meded

Kapandı be-tezvīr-i ehl-i hased

Erācīfe bā'is olur șoḥbeti

Denip dūra țard etdiler 'İzzet'i

Sakın nā-becā açma ḳaț ${ }^{\prime} \bar{a}$ dehen

Olursay da șādık çekersin ziyān

Der-enbār olan gendüm-i sebze-dār

Bu ma'nāyı eyler saya āşikār

Ḥudā șaḳlasın cümleyi ez-ḳażā

Bu hefve eder nefyini iḳtizā

Ṭarikin edip țayy ḳażā-yı Hudā

Sürer sūy-1 Sīvās'a esb-i celā

Ṭoḳuz māha vardıḳda hengām-ı hicr

Baḳın ne togurdu 'acūz-1 sipihr

Tebāşir-i șubḥ-1 kerem āh u vāh

Zuhūr itmişiken o güm-kerde rāh

Edip tengnā-yı fenādan sefer

Ṣaferde beḳāyı edindi maḳarr

Olup Şems-i Sīvāsī'ye hem-civār

Makām-1 münevver denilse ne var

Muhịbb ü mükibb ü dil-āgāh idi

Dilinde şeb ü rūz Allāh idi 
Cinānda ola peyrev-i hạāidīn

Ala bezm-i vașla anı vāṣılīn

Meded oldu işkeste cām-1 șafā

Meded söndü şem‘-i maḳām-1 șafā

Kanı öyle bir nüktedān-1 Fehīm

Yanında ḳalur lāl țab‘-1 Kelīm

Bu kạnūn-1 gerdūndır etmez galat

Yemûtu'l-kirâmu ve yebḳa's-saḳațu' ${ }^{19}$

Selefden sülāfe idi şā‘iri

Bitirdi içip hāame-i sāḥiri

Yegāne şu vādīye ḳırḳ beş sene

Sürüp at eşin bulmadı dense ne

Bu manẓūmeden başḳa dīvānı var

Şeh-i kişver-i naẓm olursa ne var

Otuz cüz kadardır o küllī eșer

Ki her biri Şehnāme-i muhtașar

Nu'ūtı olur Bür'e derd-i dile

Şefā'atle men'ūtı virsün șıla

Kașā̄id ki Nef'ī olaydı eger

Mu'āṣır çeker şöhretinden żarar

Ġazāl-i Cemāli gaazel șayd eder

Gümüşsāḳını maḳța'1 ḳayd eder

Rubā'īsini rub'-1 meskūnda nās

Sezā etseler ḳaṣr-1 naẓma esās

Bulur müfredinden revā serv-i yār

Miyān-1 muhibbānda nev-iştihār

Meșāri‘ ki āzāde ig̉lākdan

Açar beyt-i rengīne bāb-1 dehen

19 Değerli kişiler ölür ve aşağılık olan kalır. 
Tevārīh-i şināsı öyle metīn

Surūrī'yi g̀̉ıțayla itdi ḥazīn

İki meșnevīi mükerrer şeker

Müșelles șafāsı aya reşk eder

Kodu Gülşen-i 'Aşș adın birine

Hezārın getirdi huşun yerine

Șabāvet sözüyken n'ola ol sühan

Olur gāāib-i güfte-i şeyh-i fen

Diger mesnevīi ismi Nāz u Niyāz

Ușūlü ser-ā-pāy sūz u güdāz

Tamām olmadan līk ecel șad dirīg

Meh-i ‘ömrünü örtdü mānend-i mīg

Siyāh-1 huurūfa işāret edip

Yine cem‘-i dīvāna niyyet edip

Anı̣ nāmın etdi Ḩazān-ı Bahār

Birazcık da olmuş iken sebze-vār

Ne bed-fāl imiş kim o bāğ-1 nevīn

Semer vermeden oldu āfet-karīn

Eger neșre verziş edeydi tamām

Verirdi o dürre daḩı bir nizāam

Yine cā-be-cā yazdığı nāmeler

N'ola olsa ser-meşḳ-i küttāb eger

Denilmez mi dīvānı dibācesi

Görüldükde neșriy odur ḩ h̄ācesi

Kavānīn-i dersi bir üç beş sene

Göreydi gelirdi cihān dersine

Yine zūr-1 tab' ile her mațlāb1

Ezerdi ger olsa demir leblebi

Meżāmini țab'a verirdi ferāh

Eder idi Ḥaḳk’a refi'-i terāh 
Selāsetde güftārı kevser idi

'Uzūbetde ḳand-1 mükerrer idi

N'olaydı olaydı cevāhir gibi

Meżāmini șandūḳa-zīb-i lebi

Güşād etmese her maḥalde dehen

Denilmezdi zannım aya dil-şiken

Cihān her ne derse desin şānına

Ben āşüfte idim ḩod 'irfānına

Bilirdim hayātında da ḳadrini

Żiyādār ola dir idim bedrini

Kalem baya ben ana hem-derd olup

Gehī ben gehī ol boşanıp tolup

Olup mersiye-ḩَān bükā eyledik

Felekden biraz iştikā' eyledik

Dönüşde yazıp bunu gerdūnede

Hacālet getürdüy şu gerdūnede

Yeter hāāme nāçār isey de șuver

Kaderdir ḳaderdir ḳaderdir ḳader

Du'a eyle rikkatle Es'ad yeter

Ġarībü’d-diyārın niyāzı geçer

İlāhī İlāhī ecib da“vetī

Karīib eyle ihssānına 'İzzet'i

Fu'ād u Reşād u Murād'a Hudā

Dahi Ṣāliḥ’e rif'at etsin 'aṭā

Anın her biri 'İzzet' in pūrudur

Bu bī-çārenin de gözü nūrudur

Ola her biri pīr-i rūşen-żamīr

Baya göstere öyle Rabb-i ḳadīr

Meh-i maġfiretde ben etdim niyāz

Kabūl eyle fażlınla ey çāre-sāz 


\section{Âsaf Divanı, Mahmûd Celâleddin Paşa}

Bir Şā‘ir-i Meşhūruy Taḳrīzi ${ }^{20}$

Fāilātün Fāilātün Fāilātün Fāilün

Baḳ ne 'ālidir cenāb-1 Āsaf’ın divānına

Nükteler dīvān țurur țav'an 'ulüvv-i şānına

Hü̈srev-i ma'nā serīr-i nazmı tezyīn eylemiş

Ma'rifet bir yānına geçmiş edeb bir yānına

Mesnevī kit'a gazel tertīb-i dīvān eylemiş

Kā'im olmuşdur rübā'îler de çār erkānına

Bikr-i mażmūnu misāl-i kāsırātü't-țarfdır

Lü'lü'-i mensūru beyzer cennetin gilmānına

Pür-ma'ālīdir kasāid meclis-ārā söz değil

Medh-i şāhı benzemez Şehnāme'nin destānına

Pür-ḥakīkat cümlesi ez cümle ol "İntāk-1 Hak"

Hak Te‘ālā’nın güzel tefsīiridir Kur'ān'ına

"Hizb-i Baḥr"in zevki țab"-1 müstakịimi coşdurur

Çāredir ammā saḳāmet zenbinin țūfānına

Ehl-i inșāfin o sözler nag̉me-i şādīisidir

İ‘tirāz erbābının lākin ezāandır cānına

Āsaf' 1n ḳavli me‘āl-i nefha-i Cibrīil'dir

Kendi benzer Hażret-i Peyġamberin Hassān'ına

Öyle bir Āsaf ki her laḥza Süleymān-1 hyayāl

Pīş-i dīvānında gerden-dādedir fermānına

Nükte-i tevḥīd esrār-1 rümūzü'l-ġayb ile

'Ādilāne şāhid olmuş 'ilmine 'irfānına

Pek yakın eyler hafāyā-yı hakīkat inkişāf

Bir nigāh itsey uzaḳdan pertev-i ị̀ānına

20 Bu takrizler Süleymaniye Kütüphanesi İhsan Mahvi 94 (İstanbul 1896) numaralı matbu eserde 2-9 sayfa aralı̆̆ında yer almaktadır. 
Nur-1 bīniş andadır ansız ḳaranlıḳdır cihān

'Ayn-1 insān belki de 'aynın bedel insānına

Menfez-i Rūhü'l-Kudüsdür ol dehān-1 dürr-feşān

Her demi beyzer Hudā'nın nefḩa-i Rahmānına

Şānını tavsīfden 'ācizsin ey [...] fakat

'Aczini 'afv etmemek düşmez o zâtı̣ şānına

İstanbul

Fì 15 Mart sene 1314 (1896-1897)

Bir Şā‘ir-i Nükte-perverindir

Takrīz

Feūlün Feūlün Feūlün Fe'ūl

Hayālen göründi baya Enverī

O sāhib-ḳıān-1 cihān-1 Derī

Dedim söyle kim muḥriz-i nāmdır

Bugün kim sezā-vār-1 ikrāmdır

Kimin fikridir rūşen ü tāb-nāk

Kimin kilki eyler seni ġbta-nāk

İşāret edip cānib-i pākine

Bu yolda hitāō etdi fitrākine

Sürūş-1 sipihr-asitān-1 süḩan

Hümā-yı bülend-āşiyân-ı sühan

Senindir bugün mülk-i dānişverī

Senindir serīr-i sühan-perverī

Elinde ḳalem āteş-efrūzdur

Gehī rīz ü cān-bahş̧ u dil-dūzdur

O kilkin bi-‘aynih niyām-1 ḳazā

Nikāt-1 defīni hüsām-1 ḳazâ

Veya bir güzīn mürg̀-1 hoş-fāldir

Oya fikr-i perverde şeh-bāldir

Ederse benānında taḥrīk per

Olur kāḩ-1 endiş̧e zīr ü zeber 
Olaydı bugün zinde Dānā-yı Tūs

Olurdu saya muṭlaḳā pāy-būs

O Mahmûd rüsvā-yı 'āmm eyledi

Senin ḩâmen ibkā-yı nām eyledi

O "Hizb"-i güzīden o "İntāk-1 Haḳḳ"

Sır-1 nāme-i fikret-i mā-sebak

'Arabdan 'Acemden gelen şā'irān

İşitmiş mi hiç böyle bir dāsitān

Kelāmın ḩ̧oş-üslūb u dil-cūydur

Çemen-zār-1 țab'ın da ḩoş-būydur

Sitāyiş-gerindir zebān-1 'umūm

Senijle mübāhāt eder mülk-i Rūm

Sana yāver olsun Debīr-i felek

Maḥāmid-güzārın da Tīr-i felek

Cihānda yaşa ḩoş-dil ü şād-kām

Müsaḩhar yedinde ḥusūl-i merām

$\mathrm{Bu}[\ldots]$ saya bir kemīn-bendedir

'İnāyetine ḳarşı şermendedir

Eyā kām-kār-1 kerem-güsterim

Hudā'dan uzun bir 'ömür isterim

Ki hakk eyleyem evc-i mihr üstüne

Niṭậ-ı ḳavìyim sipihr üstüne

Huısāl-i dil-ārā vü dil-bendini

Mezāyā-yı bī-misl ü mānendini

Çamlica

Fî 5 Teşrīn-i Sānī sene 1314 (1896-1897) 


\section{Kaynaklar}

Arat, Reşit Rahmeti (Haz.) (2006). Atabetül-Hakayık, Ankara: Atatürk Kültür, Dil ve Tarih Yüksek Kurumu Yayınları. lar1. (Haz.) (2007). Kutadgu Bilig, Ankara: Türk Dil Kurumu Yayın(1987). Makaleler 1, Haz. Osman Fikri Sertkaya. Ankara: Türk Kültürü Araştırma Enstitüsü.

Arslan, Mehmet (2005). Üss-i Zafer. İstanbul: Kitabevi Yayınları. Kitabevi. (2010). Osmanlı Saray Taribi I, III (Tarih-i Enderûn), İstanbul:

Avşar, Ziya (2011). Aş̧k Meclisi: Mesneviye Yeniden Uyanmak, Yozgat: Kün Yayıncilik.

Aydoğan, Fatih (2003). "Sahaflar Şeyhizâde Es'ad Mehmed Efendi Divanı", yayımlanmamı̧ yüksek lisans tezi, Ankara: Gazi Üniversitesi.

Bauer, Thomas (2014). "How to create a network: Zaynaddin al-Atari", Everthing is on the Move: The Mamluk Empires as a Node in (Trans-) Regional Networks, Ed. Stephan Conermann, Germany: Bonn University Press, s. 205-211.

https://books.google.com.tr/books?id=gPZ_BgAAQBAJ\&pg=PA20 $5 \& \mathrm{lpg}=\mathrm{PA} 205 \& \mathrm{dq}=$ Thomas + Bauer,$+\% 22 \mathrm{How}+$ to + Create $+\mathrm{a}+\mathrm{Networ}$ $\mathrm{k}:+$ Zaynaddin $+\mathrm{al}-$

Burak, Guy (2015). "Sansür, Kanonizasyon ve Osmanlı İmzâ-Takrîz Pratikleri üzerine Düşünceler”, Osmanlı Edebiyatı Callşmaları X: Eski Metinlere Yeni Bağlamlar: Osmanlı Edebiyatı Çalısmalarında Yeni Yönelimler, İstanbul: Klasik Yayınları.

Ceylan, Ömür-Ozan Y1lmaz (2005). Hazana Sürgün Bir Bahar, İstanbul: Kitap Saray1.

Ceylan, Ömür (2003). Âsaf Divanı: Hânedânda Bir Asi ÂsafDâmâd Mahmûd Cemâleddin Paşa (Hayatı, Edebî Kişiliğgi ve Divanı), Ankara: Akçağ Yayınları.

Çavuşoğlu, Mehmet (1991). “Bâkî”, Türkiye Diyânet Vakfı İslâm Ansiklopedisi, Cilt: 4, s.537-540.

Çavuşoğlu, Mehmet (1983). Yahya Bey ve Divanından Örnekler, Ankara: Kültür ve Turizm Bakanlığı.

Elçi, Fatih (2016). “Nevres-i Kadim’in Münşeât'ında Yer Alan Eleştiri İçerikli İki Takriz", Journal of Turkish Language and Literature, Volume:2, Issue: 1, Winter, s.139-152.

Gür, Nagihan (2012). "Klâsik Metinlerin Nazar Duaları: Takrîzler ve Ye- 
nipazarlı Vâlîye Yazılan Takrîzler Üzerine”, İstanbul: İstanbul Kültür Üniversitesi Yayınları.

(2014). “Klasik Türk Edebiyatında Takriz Geleneği”, yayınlanmamış doktora tezi, Balıkesir: Balıkesir Üniversitesi.

İnal, İbnülemin Mahmûd Kemâl (1988). Son Asır Türk Şairleri I-IV, İstanbul: Dergâh Yayınları.

İpekten, Haluk (2008). Bâkî: Hayatı, Edebî Kişiliği ve Bazı Şiirlerinin Açılamaları, Ankara: Akçă̆ Yayınları.

İstanbul Kütüphaneleri Türkçe Yazma Divanlar Kataloğu (1965), IV. Cildi, Fasikül III, İstanbul: Milli Eğitim Bakanlığı.

Karataş, Turan (2004). Edebiyat Terimleri Sözlüğü, Ankara: Akçă̆ Yayınları.

Kartal, Ahmet (2008). Şiraz'dan İstanbul'a Şiir Rüzgarları: Türk-Fars Kültür Coğrafyası Üzerine Araştırmalar, İstanbul: Kriter Yayınları.

Keçecizade İzzet Molla (1841). Divançe-i İzzet (Hazan-ı Asar), İstanbul.

Köksal, Fatih (2012). Eski Türk Edebiyatında Tenkit ve Teori, İstanbul: Kesit Yayınlar1.

Köprülü, Mehmet Fuat (1979). "Bâkî”, Milli Eğitim Bakanlığg İslâm Ansiklopedisi, C.2.s.249.

114 Kuntay, Midhat Cemal (1949). Namık Kemâl: Devrinin İnsanları ve Olayları Arasında, Ankara: Milli Ĕ̆itim Bakanlığı.

Levanoni, Amalia (2013). "A Supplementary Source for the Study of Mamluk Social History: The Taqârîz”, Arabica 60, s.146-177.

Mehmed Süreyya (1996), Sicill-i Osmanî III-IV, Haz. Nuri Akbayar ve Seyit Ali Kahraman, İstanbul: Tarih Vakfi Yurt Yayınları 30.

Muallim Naci (2009), “Takriz”, Lügat-i Naci, Haz. Ahmet Kartal, Ankara: Türk Dil Kurumu Yayınları.

Oğraş, Rıza (2001). Es'ad Mehmed Efendi ve Bağģe-i Safâ-Endûz'u (İncelememetin) Burdur. bttp://ekitap.kulturturizm.gov.tr/dosya/1-219113/b/ bahce.pdf (04.10.2012)

Okçu, Naci (2001). "İzzet Molla, Keçecizâde", Türkiye Diyânet Vakfi İslâm Ansiklopedisi, C.23, s.561-563.

Onay, Ahmet Talât (2000). Eski Türk Edebiyatında Mazmunlar ve İzahı, Ankara: Akçă̆ Yayınları.

Özgül, M. Kayahan (2013). "Edebiyat Tarihine Manifestik Bir Bakı̧", Turkish Studies - International Periodical For The Languages, Literature and History of Turkish or Turkic Volume 8/9 Summer, s.2685-2700.

Özy1ldırım, Ali Emre (2007). Keçecizâde İzzet Molla ve Mihnetkeşân Part I, Cambridge Mass.: Harvard Üniversitesi Yakındoğu Dilleri ve Medeniyetleri Bölümü. 
Pala, İskender (2003). "Leskofçalı Gâlib”, Türkiye Diyânet Vakfi İslâm Ansiklopedisi, C.27, s.140-141.

Rosenthal, Franz (1981). "Blurbs (Taqriz) From Fourteenth-Centruy Egypt" Oriens, Vol: 27/28, 177-196. http:\{www.jstor.org/stable/1580566. (21.07.2011)

Sahaflar Şeyhizâde Es'ad Efendi Divan. Süleymaniye Kütüphanesi Esad Efendi 1749.

Şahin, Eburbekir Sıddık (2013). "Hüsn ü Aşk'ın İzinde Yarım Kalan Bir Mesnevî: Nâz u Niyâz", Ankara Üniversitesi Dil ve Tarih-Coğrafya Fakültesi Türkoloji Dergisi 20-1, s.145-184.

Güncel Türkçe Sözlük (2015). “Takriz”, Ankara: Türk Dil Kurumu.

Tüzin, Derya (2008). "Sürgün Yolunda Bir Yenileşme Serüveni: MibnetKeşân”, yayımlanmamış yüksek lisans tezi, Ankara: Bilkent Üniversitesi.

Uzun, Mustafa-Ahmet Turan Arslan (2010). “Takriz”, TürkiyeDiyanet İslam Ansiklopedisi, C.39, s.472-474.

Vesely, Rudolf (2003)."Das Takriz in der arabischen Literatur”,Die Memlûken -Studien zuibrer Geschichte und Kultur. Zum Gedenken an Ulrich Haarmann (1942-1999), Stephan Conermann-Anja Pistor-Hatam (Hg.). s.379-385.

Woodhead, Christine (2000). "Puff and Patronaj: Ottoman takriz-writing and literary recommendation in the 17th century", The Balance of the truth. Essays in honour of Professor Geoffrey Lewis, Ed. Çiğdem BalımHarding, C. Imber, İstanbul: Isis Press, s.395-406.

Yıldız, Ahmet Hamit (2003). "Leskofçalı Gâlib, Hayatı Dönemi Sanatı Divanı ve Metnin Bugünkü Türkçesi”, yayımlanmamış yüksek lisans tezi, İstanbul: Boğaziçi Üniversitesi.

Y1lmazer, Ziya (1995). "Es’ad Efendi, Sahaflar Şeyhizâde”, Türkiye Diyânet Vakfi İslâm Ansiklopedisi, C.11, s.341-345. 


\section{ABSTRACT \\ Takriz Texts as a Source of Literary History Writing and Two Unusual Examples}

Takriz-writing has an important place in the tradition of Ottoman literature. Takriz created its own tradition and this tradition can be considered as a primary source for studies on the Ottoman literature. Takriz refers to a short statement of praise in verse or prose to promote the book and the writer and usually attached to the works' cover. Some takriz examples contain valuable information about writers and works which can be used as sources for carrying out biographical and monographic studies. This study discusses the functions of takriz as a primary source for literary history-writing. In this regard, this article analyzes the content of some takriz which were written for MibnetKeşân and ÂsafDivanı. Besides, this article reveals the importance and the function of the takriz texts in terms of re-writing the history of Ottoman literature and contributing to the biography-writing.

Keywords: Takriz-tradition, literary history writing, Ottoman literature, Keçecizâde İzzet Molla, Mißnnet-Keşân, Mahmûd Celâleddin Paşa, Asaf Divanı (collected poems of Âsaf) 